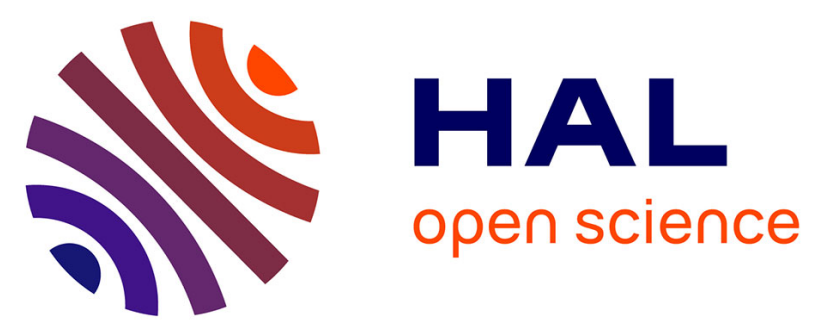

\title{
Synthesis and anion exchange chemistry of new intercalation hosts containing lanthanide cations, $\operatorname{Ln}(\mathrm{OH})(\mathrm{NO}) . \mathrm{Ho}(\mathrm{Ln}=\mathrm{Y}, \mathrm{Gd}-\mathrm{Lu})$
}

\author{
Laura J. Mcintyre, Lauren K. Jackson, Andrew M. Fogg
}

\section{To cite this version:}

Laura J. Mcintyre, Lauren K. Jackson, Andrew M. Fogg. Synthesis and anion exchange chemistry of new intercalation hosts containing lanthanide cations, $\operatorname{Ln}(\mathrm{OH})(\mathrm{NO}) \cdot \mathrm{Ho}(\mathrm{Ln}=\mathrm{Y}$, Gd-Lu). Journal of Physics and Chemistry of Solids, 2009, 69 (5-6), pp.1070. 10.1016/j.jpcs.2007.11.004 . hal-00516165

\section{HAL Id: hal-00516165 \\ https://hal.science/hal-00516165}

Submitted on 9 Sep 2010

HAL is a multi-disciplinary open access archive for the deposit and dissemination of scientific research documents, whether they are published or not. The documents may come from teaching and research institutions in France or abroad, or from public or private research centers.
L'archive ouverte pluridisciplinaire HAL, est destinée au dépôt et à la diffusion de documents scientifiques de niveau recherche, publiés ou non, émanant des établissements d'enseignement et de recherche français ou étrangers, des laboratoires publics ou privés. 


\section{Author's Accepted Manuscript}

Synthesis and anion exchange chemistry of new intercalation hosts containing lanthanide cations, $\mathrm{Ln}_{2}(\mathrm{OH})_{5}\left(\mathrm{NO}_{3}\right) \cdot x \mathrm{H}_{2} \mathrm{O}(\mathrm{Ln}=\mathrm{Y}, \mathrm{Gd}-\mathrm{Lu})$

Laura J. McIntyre, Lauren K. Jackson, Andrew M. Fogg

PII: $\quad$ S0022-3697(07)00718-4

DOI: $\quad$ doi:10.1016/j.jpcs.2007.11.004

Reference: $\quad$ PCS 5308

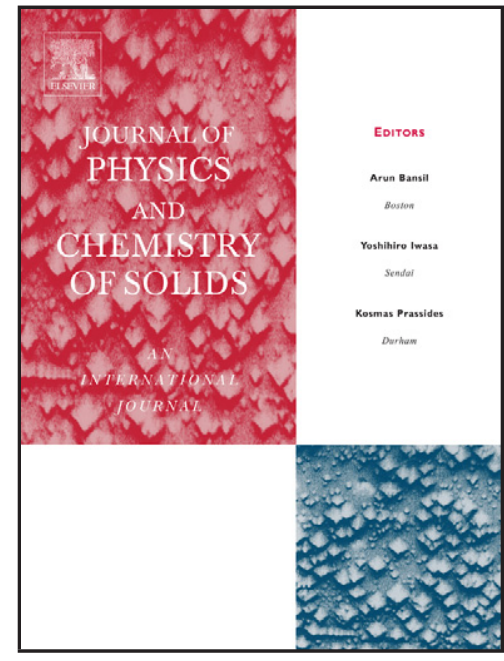

www.elsevier.com/locate/jpcs

To appear in: $\quad$ Journal of Physics and Chemistry of Solids

Received date: $\quad 28$ June 2007

Accepted date: $\quad 2$ November 2007

Cite this article as: Laura J. McIntyre, Lauren K. Jackson and Andrew M. Fogg, Synthesis and anion exchange chemistry of new intercalation hosts containing lanthanide cations, $\mathrm{Ln}_{2}(\mathrm{OH})_{5}\left(\mathrm{NO}_{3}\right) \cdot x \mathrm{H}_{2} \mathrm{O}(\mathrm{Ln}=\mathrm{Y}, \mathrm{Gd}-\mathrm{Lu})$, Journal of Physics and Chemistry of Solids (2007), doi:10.1016/j.jpcs.2007.11.004

This is a PDF file of an unedited manuscript that has been accepted for publication. As a service to our customers we are providing this early version of the manuscript. The manuscript will undergo copyediting, typesetting, and review of the resulting galley proof before it is published in its final citable form. Please note that during the production process errors may be discovered which could affect the content, and all legal disclaimers that apply to the journal pertain. 
Conference Proceeding: ISIC14, Seoul, 12-15 ${ }^{\text {th }}$ June 2007

Synthesis and anion exchange chemistry of new intercalation hosts containing lanthanide cations, $\mathrm{Ln}_{2}(\mathrm{OH})_{5}\left(\mathrm{NO}_{3}\right) \cdot x \mathrm{H}_{2} \mathrm{O}(\mathrm{Ln}=\mathrm{Y}, \mathrm{Gd}-\mathrm{Lu})$

Laura J. McIntyre, Lauren K. Jackson and Andrew M. Fogg*

Department of Chemistry, University of Liverpool, Liverpool, L69 7ZD, U.K.

* To whom all correspondence should be addressed

Tel : 441517942047

Fax : 441517943587

E-mail : afogg@liverpool.ac.uk 


\begin{abstract}
A new class of lanthanide containing layered hydroxides, with the composition $\mathrm{Ln}_{2}(\mathrm{OH})_{5} \mathrm{NO}_{3} . x \mathrm{H}_{2} \mathrm{O}(\mathrm{Ln}=\mathrm{Y}, \mathrm{Gd}-\mathrm{Lu})$, has been synthesised via a hydrothermal route. These materials combine the properties of the lanthanides with the flexibility of intercalation hosts and comprise cationic layers containing a single lanthanide cation with charge neutrality maintained by the nitrate anions between the layers. Powder Xray diffraction and TEM studies indicate that they have a monoclinic structure. Additionally, powder XRD data show that $\mathrm{Gd}_{2}(\mathrm{OH})_{5} \mathrm{NO}_{3} \cdot x \mathrm{H}_{2} \mathrm{O}$ is significantly less crystalline than the other phases and it has not yet proved possible to synthesise this phase with any of the larger lanthanides. The capacity of the $\mathrm{Ln}_{2}(\mathrm{OH})_{5} \mathrm{NO}_{3} \cdot x \mathrm{H}_{2} \mathrm{O}(\mathrm{Ln}=$ Y, Gd - Lu) materials for anion exchange chemistry has been demonstrated by their facile reactions with a range of inorganic and organic anions including sulfate, carbonate, aliphatic and aromatic dicarboxylates and disulfonates forming materials with the general composition $\mathrm{Ln}_{2}(\mathrm{OH})_{5} \mathrm{~A}_{0.5} \cdot x \mathrm{H}_{2} \mathrm{O}$.
\end{abstract}

Keywords: A. inorganic compounds, B. chemical synthesis, C. X-ray diffraction 


\section{Introduction}

Materials capable of undergoing anion exchange reactions, in particular layered hydroxides, have attracted significant interest as hosts for intercalation reactions. These are unusual materials amongst intercalation hosts, consisting of positively charged layers and charge balancing anions in the interlayer regions which can be readily replaced by other species through an anion exchange process.[1] Research into this area is dominated

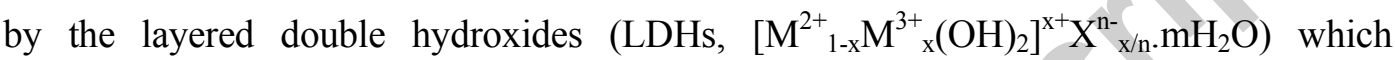
comprise a divalent (e.g. $\mathrm{M}^{2+}=\mathrm{Mg}, \mathrm{Zn}, \mathrm{Co}, \mathrm{Ni}$ ) and a trivalent cation (e.g. $\mathrm{M}^{3+}=\mathrm{Al}, \mathrm{Cr}$, $\mathrm{Fe}, \mathrm{Ga}$ ) within the layers.[2-4] Intercalation reactions provide routes to both modify and control the electrical, optical and magnetic properties of the material with only a minimal change in the structure and layered double hydroxides themselves have found numerous applications in fields as diverse as catalysis, medicine and molecular recognition.[5]

Whilst it has proved possible to intercalate lanthanide containing guests into LDHs[6] there have been no reports of the cations being incorporated into the layers of these intercalation host lattices. The larger lanthanides are known to form layered hydroxynitrates with the general formula $\mathrm{Ln}(\mathrm{OH})_{2} \mathrm{NO}_{3} \cdot \mathrm{H}_{2} \mathrm{O}(\mathrm{Ln}=\mathrm{La}, \mathrm{Pr}, \mathrm{Nd}$, Sm and Gd; $x=0,1)[7-10]$ and anion exchange has been demonstrated for reactions between $\mathrm{La}(\mathrm{OH})_{2} \mathrm{NO}_{3} \cdot \mathrm{H}_{2} \mathrm{O}$ and acetate, benzoate and terephthalate salts.[11] 
In this paper we report the synthesis and anion exchange chemistry of a new family of hydroxynitrates with the general formula $\mathrm{Ln}_{2}(\mathrm{OH})_{5} \mathrm{NO}_{3} \cdot x \mathrm{H}_{2} \mathrm{O}(\mathrm{Ln}=\mathrm{Y}, \mathrm{Gd}-\mathrm{Lu})$. These materials are the first anion exchange host lattices to incorporate the smaller lanthanide cations within the layers and have the potential to combine the properties of the lanthanide elements, for example optical and catalytic, with the flexibility of lamellar intercalation hosts.

\section{Experimental Details}

\subsection{Synthesis of $\mathrm{Ln}_{2}(\mathrm{OH})_{5} \mathrm{NO}_{3} \cdot \mathrm{xH}_{2} \mathrm{O}(\mathrm{Ln}=\mathrm{Y}, \mathrm{Gd}-\mathrm{Lu})$}

The $\mathrm{Ln}_{2}(\mathrm{OH})_{5} \mathrm{NO}_{3} \cdot x \mathrm{H}_{2} \mathrm{O}(\mathrm{Ln}=\mathrm{Y}, \mathrm{Gd}-\mathrm{Lu})$ phases are synthesised via a hydrothermal route. In a typical reaction $7.5 \mathrm{~mL}$ of a $0.44 \mathrm{M} \mathrm{Ln}\left(\mathrm{NO}_{3}\right)_{3} \cdot x \mathrm{H}_{2} \mathrm{O}$ aqueous solution is added to $2.5 \mathrm{~mL}$ of an aqueous solution containing $2.10 \mathrm{M} \mathrm{NaOH}$ and $1.44 \mathrm{M} \mathrm{NaNO}_{3}$ and treated hydrothermally at $150^{\circ} \mathrm{C}\left(125^{\circ} \mathrm{C}\right.$ for $\left.\mathrm{Y}\right)$ for 48 hours. The resulting solid was filtered, washed and allowed to dry in air.

\subsection{Anion exchange reactions}

Anion exchange reations were performed between the $\mathrm{Ln}_{2}(\mathrm{OH})_{5} \mathrm{NO}_{3} \cdot x \mathrm{H}_{2} \mathrm{O}(\mathrm{Ln}=\mathrm{Y}, \mathrm{Gd}-$ Lu) phases and an aqueous solution containing a threefold molar excess of a range of (di)sodium salts of organic anions at room temperature. The anions investigated were maleate, fumarate, phthalate, terephthalate, oxalate, malonate, succinate, glutarate, 
suberate and decylsulfonate. All the chemicals were supplied by Aldrich and used without further purification.

\section{Results and discussion}

A new family of hydroxynitrates, having the composition $\mathrm{Ln}_{2}(\mathrm{OH})_{5} \mathrm{NO}_{3} \cdot \mathrm{xH}_{2} \mathrm{O}(\mathrm{Ln}=\mathrm{Y}$, $\mathrm{Gd}-\mathrm{Lu}$ ), has been synthesised via a hydrothermal route. As these materials are isostructural and display similar behaviour in anion exchange reactions they will be exemplified here by the phase with $\mathrm{Ln}=\mathrm{Y}$. In each case the materials were synthesised phase pure and the composition, $\mathrm{Ln}_{2}(\mathrm{OH})_{5} \mathrm{NO}_{3} \cdot x \mathrm{H}_{2} \mathrm{O}(x \approx 1)$, was confirmed by elemental analysis and thermogravimetric analysis as summarised in Table 1. The samples comprise microcrystalline powders with an approximately hexagonal plate-like morphology as shown by the SEM image in Fig. 1 for $\mathrm{Y}_{2}(\mathrm{OH})_{5} \mathrm{NO}_{3} \cdot x \mathrm{H}_{2} \mathrm{O}$.

The TGA data (Fig. 2) display three mass losses, typical of those seen for LDHs. For $\mathrm{Y}_{2}(\mathrm{OH})_{5} \mathrm{NO}_{3} . x \mathrm{H}_{2} \mathrm{O}, 6.86 \%$ of the mass is lost below $150{ }^{\circ} \mathrm{C}$ corresponding to the loss of co-intercalated water with further mass losses of $9.79 \%$ by $350{ }^{\circ} \mathrm{C}$ and $17.28 \%$ by 650 ${ }^{\circ} \mathrm{C}$ corresponding to the decomposition of layers and the nitrate anion leaving $\mathrm{Y}_{2} \mathrm{O}_{3}$.[12] No further mass loss is observed above $650{ }^{\circ} \mathrm{C}$.

The phase purity of these materials was confirmed by powder X-ray diffraction which showed strong $(00 l)$ reflections characteristic of a layered material. The powder XRD pattern for $\mathrm{Y}_{2}(\mathrm{OH})_{5} \mathrm{NO}_{3} . x \mathrm{H}_{2} \mathrm{O}$ is shown in Figure 3. In addition to the strong basal 
reflections a large number of non-basal reflections are observed indicating that there is significant order within the layers in contrast to many of the LDHs. The data can be fully indexed on a monoclinic unit cell which refined to $a=7.0808(4) \AA, b=12.7004(5) \AA, c$ $=18.6348(4) \AA$ and $\beta=92.509(5)^{\circ}$ in a Le Bail extraction. TEM has confirmed the $a$ and $b$ parameters and revealed that there are no systematic absences in the $a b$ plane (see inset to Fig. 3). Unfortunately, due to the plate-like morphology of the crystals (see Fig. 1), and despite extensive screening, it was not possible observe diffraction from along the $c$-axis. Whilst attempts to fully determine the crystal structure of the $\mathrm{Ln}_{2}(\mathrm{OH})_{5} \mathrm{NO}_{3} \cdot x \mathrm{H}_{2} \mathrm{O}$ materials are ongoing, the lattice parameters suggest that they have a layer structure similar the recently reported orthorhombic $\left[\mathrm{Ln}_{4}(\mathrm{OH})_{10}\left(\mathrm{H}_{2} \mathrm{O}\right)_{4}\right] \mathrm{A}(\mathrm{Ln}=\mathrm{Y}$, Dy, Ho, Yb; A = 2,6-naphthalenedisulfonate, 2,6-anthraquinonedisulfonate) phases which were prepared directly via a hydrothermal route.[13] Single crystal studies revealed them to consist of cationic layers in which the lanthanide cations are 8 and 9 coordinate to hydroxide and additionally coordinated to water with charge neutrality maintained by the organic anions in the interlayer space. In the current study, however, despite extensive optimisation of the reaction conditions through control of the temperature, reagent concentration and time, it has not proved possible to obtain single crystals of $\mathrm{Ln}_{2}(\mathrm{OH})_{5} \mathrm{NO}_{3} \cdot x \mathrm{H}_{2} \mathrm{O}$ suitable for X-ray diffraction or to index the powder X-ray diffraction data on orthorhombic unit 
cells related to those reported by Gándara et al. Powder XRD data show that $\mathrm{Gd}_{2}(\mathrm{OH})_{5} \mathrm{NO}_{3} \cdot x \mathrm{H}_{2} \mathrm{O}$ is significantly less crystalline than the other materials and it has not proved possible to synthesise this phase with any of the larger lanthanides.

The data discussed above are consistent with the formation of a new family of layered lanthanide hydroxynitrates in which the positively charged layers contain a single lanthanide cation with charge neutrality maintained by the nitrate anion. One characteristic property of layered hydroxide materials, such as LDHs, is their ability to undergo facile anion exchange reactions with a wide variety of inorganic and organic anions. Experiments with the new $\mathrm{Ln}_{2}(\mathrm{OH})_{5} \mathrm{NO}_{3} \cdot x \mathrm{H}_{2} \mathrm{O}$ materials have demonstrated that the nitrate ions can be completely replaced by reaction with a range of inorganic ions and organic carboxylates and sulfonates at room temperature as evidenced by the absence of reflections characteristic of the host phase in the powder X-ray diffraction patterns and of nitrogen in the elemental analysis. Successful anion exchange reactions, forming $\mathrm{Ln}_{2}(\mathrm{OH})_{5} \mathrm{~A}_{0.5} \cdot x \mathrm{H}_{2} \mathrm{O}(x \approx 1.5)$, have been observed with, for example, sulfate, carbonate and the disodium salts of aliphatic dicarboxylic acids, fumaric, maleic, phthalic and terephthalic acids and the sodium salt of decylsulfonic acid and all the host materials giving rise to interlayer separations of up to $26 \AA$ clearly demonstrating the flexibility of these materials for intercalation chemistry. Typical diffraction patterns of the anion 
exchange products are shown in Fig. 4 and characterising data given in the ESI. TGA traces of the organic intercalation compounds are comparable to those, for example, of the LDHs showing the loss of co-intercalated water below $150{ }^{\circ} \mathrm{C}$ followed by the dehydroxylation of the layers and decomposition of the guest anions. From an analysis of the interlayer separtaions of the aliphatic dicarboxylate intercalates it is possible to deduce an approximate orientation of the anions between the lanthanide hydroxide layers. The plot of interlayer separation against the number of $\mathrm{CH}_{2}$ groups in the chain is shown in Figure 5 from which a gradient of $1.17 \AA / \mathrm{C}$ atom is obtained. By comparing this with the intrachain C-C distance in hydrocarbons of approximately $1.27 \AA$ it is possible to calculate a guest orientation of approximately $67^{\circ}$ with respect to the layers which is comparable to that seen in similar LDH systems.[14, 15]

\section{Conclusions}

We report in this paper the first synthesis of a new class of layered hydroxides with layers containing the smaller lanthanide cations with the general formula, $\mathrm{Ln}_{2}(\mathrm{OH})_{5} \mathrm{NO}_{3} \cdot x \mathrm{H}_{2} \mathrm{O}$ $(\mathrm{Ln}=\mathrm{Y}, \mathrm{Gd}-\mathrm{Lu})$. Thorough characterisation has confirmed the composition and the layered nature of these materials has been shown by the complete replacement of the nitrate anions between the layers by organic anions in facile exchange reactions. Full details of all the $\mathrm{Ln}_{2}(\mathrm{OH})_{5} \mathrm{NO}_{3} \cdot x \mathrm{H}_{2} \mathrm{O}(\mathrm{Ln}=\mathrm{Y}, \mathrm{Gd}-\mathrm{Lu})$ materials, their structure and 
anion exchange chemistry will be reported elsewhere along with details of solid solution formation between the nitrate hosts and doping of the larger lanthanides into these materials.

Acknowledgements We would like to thank Dr Mathieu Allix for the microscopy and EPSRC for funding under EP/D060664. AMF thanks the Royal Society for a University Research Fellowship.

\section{References}

1. D. G. Evans, and R. C. T. Slade, Structural aspects of layered double hydroxides, in Layered Double Hydroxides, Structure and Bonding, 119 (2006) 1-87.

2. A. I. Khan, and D. O'Hare, Intercalation chemistry of layered double hydroxides: recent developments and applications, J. Mater. Chem. 12 (2002) 3191-3198. 3. V. Rives, Layered Double Hydroxides: Present and Future, ed., Nova Science Publishers, New York 2001.

4. G. R. Williams, and D. O'Hare, Towards understanding, control and application of layered double hydroxide chemistry, J. Mater. Chem.16 (2006) 3065-3074.

5. L. Feng, and X. Duan, Applications of layered double hydroxides, in Layered Double Hydroxides, Structure and Bonding, 119 (2006), 193-223.

6. S. Gago, M. Pillinger, R. A. S. Ferreira, L. D. Carlos, T. M. Santos, and I. S. Goncalves, Immobilization of lanthanide ions in a pillared layered double hydroxide, Chem. Mater. 17 (2005) 5803-5809.

7. D. Louer, and M. Louer, Crystal-Structure Of $\mathrm{Nd}(\mathrm{OH})_{2} \mathrm{NO}_{3} \cdot \mathrm{H}_{2} \mathrm{O}$ Completely Solved And Refined From X-Ray-Powder Diffraction, J Solid State Chem. 68 (1987) 292-299.

8. M. Louer, D. Louer, A. L. Delgado, and O. G. Martinez, The Structures Of Lanthanum Hydroxide Nitrates Investigated By The Rietveld Profile Refinement Technique, Eur. J. Solid State Inorg. Chem. 26 (1989) 241-253.

9. M. Lundberg, and A. J. Skarnulis, Crystal-Structure Of $\operatorname{Pr}(\mathrm{OH})_{2} \mathrm{NO}_{3}$, Acta Crystallogr. B 32 (1976) 2944-2947.

10. D. F. Mullica, E. L. Sappenfield, and D. A. Grossie, Crystal-Structure Of Neodymium And Gadolinium Dihydroxy-Nitrate, $\mathrm{Ln}(\mathrm{OH})_{2} \mathrm{NO}_{3}$, J. Solid State Chem. 63 (1986) 231-236. 
11. S. P. Newman, and W. Jones, Comparative study of some layered hydroxide salts containing exchangeable interlayer anions, J. Solid State Chem. 148 (1999) 26-40. 12. I. Schildermans, J. Mullens, J. Yperman, D. Franco, and L. C. Vanpoucke, Preparation And Thermal-Decomposition Of $\mathrm{Y}_{2}(\mathrm{OH})_{5} \mathrm{NO}_{3} \cdot 1.5 \mathrm{H}_{2} \mathrm{O}$, Thermochimica Acta 231 (1994) 185-192.

13. F. Gandara, J. Perles, N. Snejko, M. Iglesias, B. Gomez-Lor, E. Gutierrez-Puebla, and M. A. Monge, Layered rare-earth hydroxides: A class of pillared crystalline compounds for intercalation chemistry, Angew. Chem.Int. Ed. 45 (2006) 7998-8001. 14. M. Borja, and P. K. Dutta, Fatty acids in layered metal hydroxides: membrane-like structure and dynamics, J. Phys. Chem. 96 (1992) 5434.

15. G. R. Williams, T. G. Dunbar, A. J. Beer, A. M. Fogg, and D. O'Hare, Intercalation chemistry of the novel layered double hydroxides $\left[\mathrm{MAl}_{4}(\mathrm{OH})_{12}\right](\mathrm{NO} 3)_{2} \cdot x \mathrm{H} 2 \mathrm{O}(\mathrm{M}=\mathrm{Zn}$, $\mathrm{Cu}, \mathrm{Ni}$ and $\mathrm{Co}$ ). 1: New organic intercalates and reaction mechanisms, J. Mater. Chem. 16 (2006) 1222-1230. 


\section{Figure captions}

Figure 1. SEM image of $\mathrm{Y}_{2}(\mathrm{OH})_{5} \mathrm{NO}_{3} \cdot x \mathrm{H}_{2} \mathrm{O}$.

Figure 2. TGA trace for $\mathrm{Y}_{2}(\mathrm{OH})_{5} \mathrm{NO}_{3} \cdot x \mathrm{H}_{2} \mathrm{O}$ showing mass losses of $6.86 \%$ below 150 ${ }^{\circ} \mathrm{C}$ and further mass losses of $9.79 \%$ by $350{ }^{\circ} \mathrm{C}$ and $17.28 \%$ by $600{ }^{\circ} \mathrm{C}$.

Figure 3. Powder X-ray diffraction pattern of $\mathrm{Y}_{2}(\mathrm{OH})_{5} \mathrm{NO}_{3} \cdot x \mathrm{H}_{2} \mathrm{O}$. Inset: SAED pattern for $\mathrm{Y}_{2}(\mathrm{OH})_{5} \mathrm{NO}_{3} \cdot x \mathrm{H}_{2} \mathrm{O}$.

Figure 4. Powder XRD diffraction patterns of (a) $\mathrm{Y}_{2}(\mathrm{OH})_{5} \mathrm{NO}_{3} \cdot x \mathrm{H}_{2} \mathrm{O}$ and the anion exchange intercalation compounds (b) $\mathrm{Y}_{2}(\mathrm{OH})_{5}\left(\mathrm{C}_{2} \mathrm{O}_{4}\right)_{0.5} \cdot x \mathrm{H}_{2} \mathrm{O}$ (c) $\mathrm{Y}_{2}(\mathrm{OH})_{5}(\mathrm{o}-$ $\left.\mathrm{C}_{6} \mathrm{H}_{4}\left(\mathrm{CO}_{2}\right)_{2}\right)_{0.5} \cdot x \mathrm{H}_{2} \mathrm{O}$ and (d) $\mathrm{Y}_{2}(\mathrm{OH})_{5}\left(\mathrm{C}_{8} \mathrm{H}_{12} \mathrm{O}_{4}\right)_{0.5} \cdot x \mathrm{H}_{2} \mathrm{O}$.

Figure 5. Plot of interlayer separation against number of $-\mathrm{CH}_{2}-$ groups in the aliphatic chain of some dicarboxylate intercalates of $\mathrm{Y}_{2}(\mathrm{OH})_{5} \mathrm{NO}_{3} \cdot x \mathrm{H}_{2} \mathrm{O}$. 
Figure 1

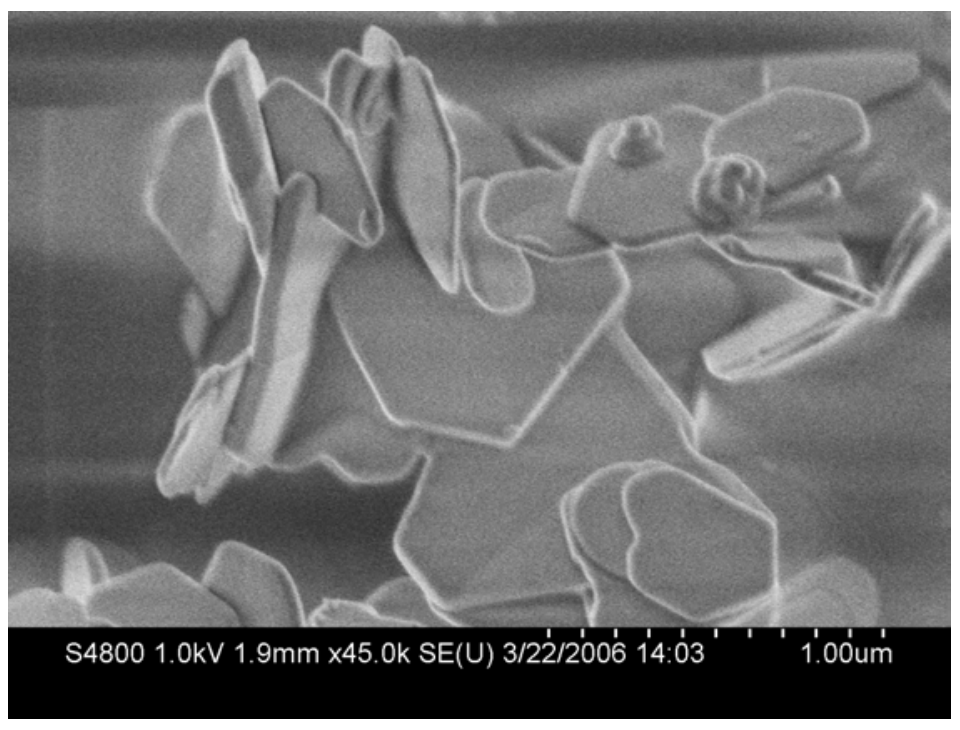




\section{Figure 2}

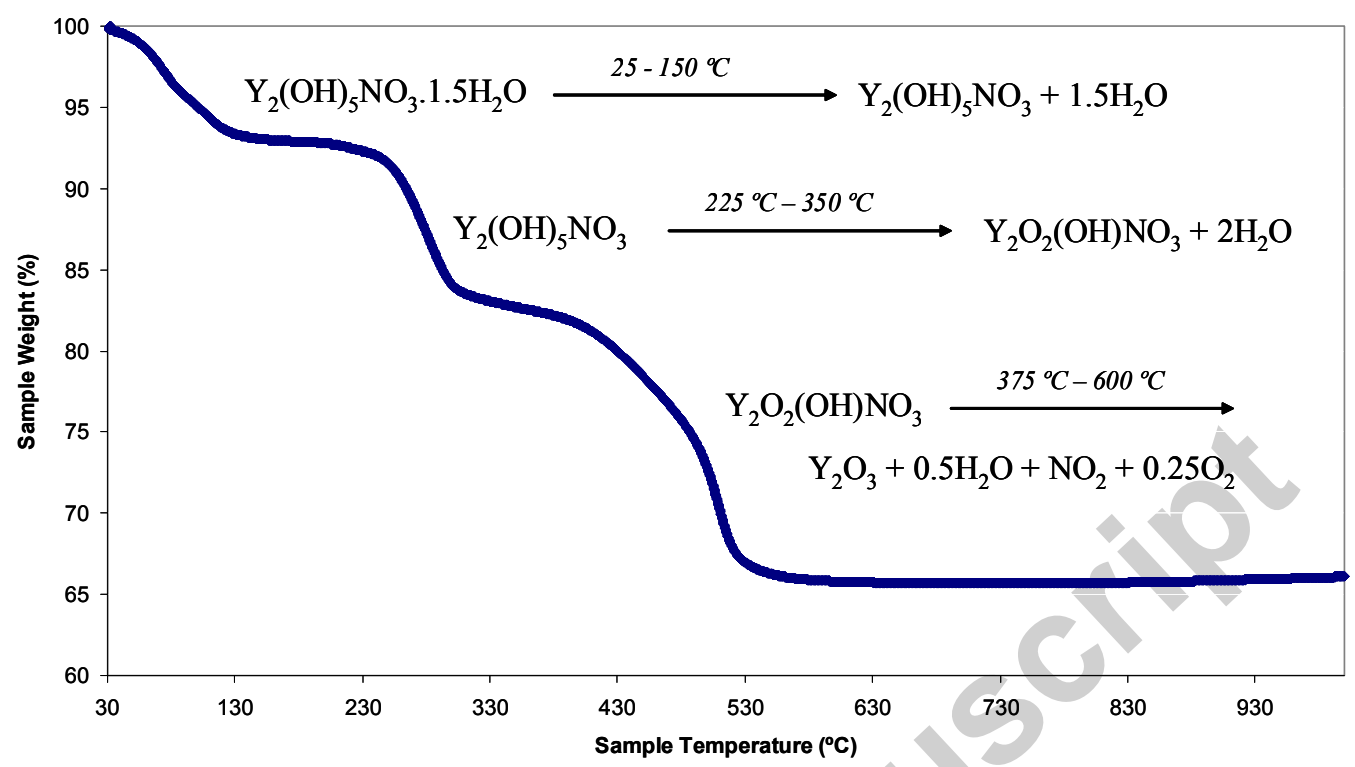


Figure 3

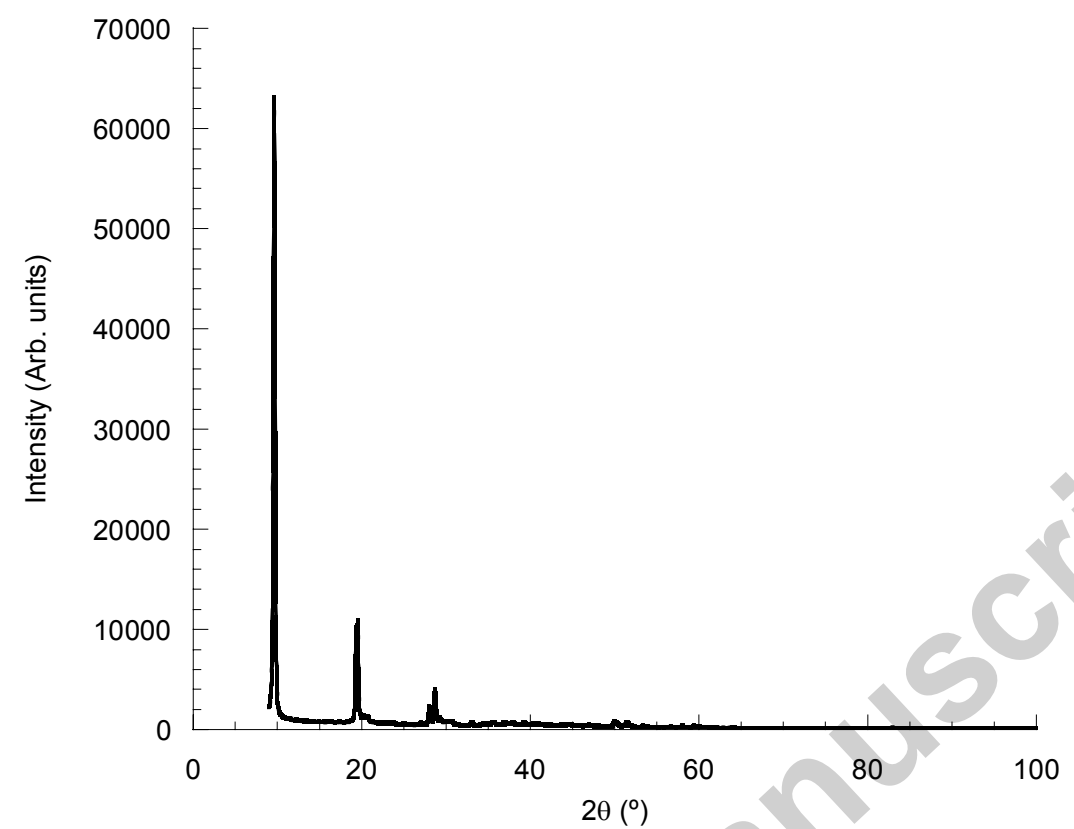

Figure 3 INSET

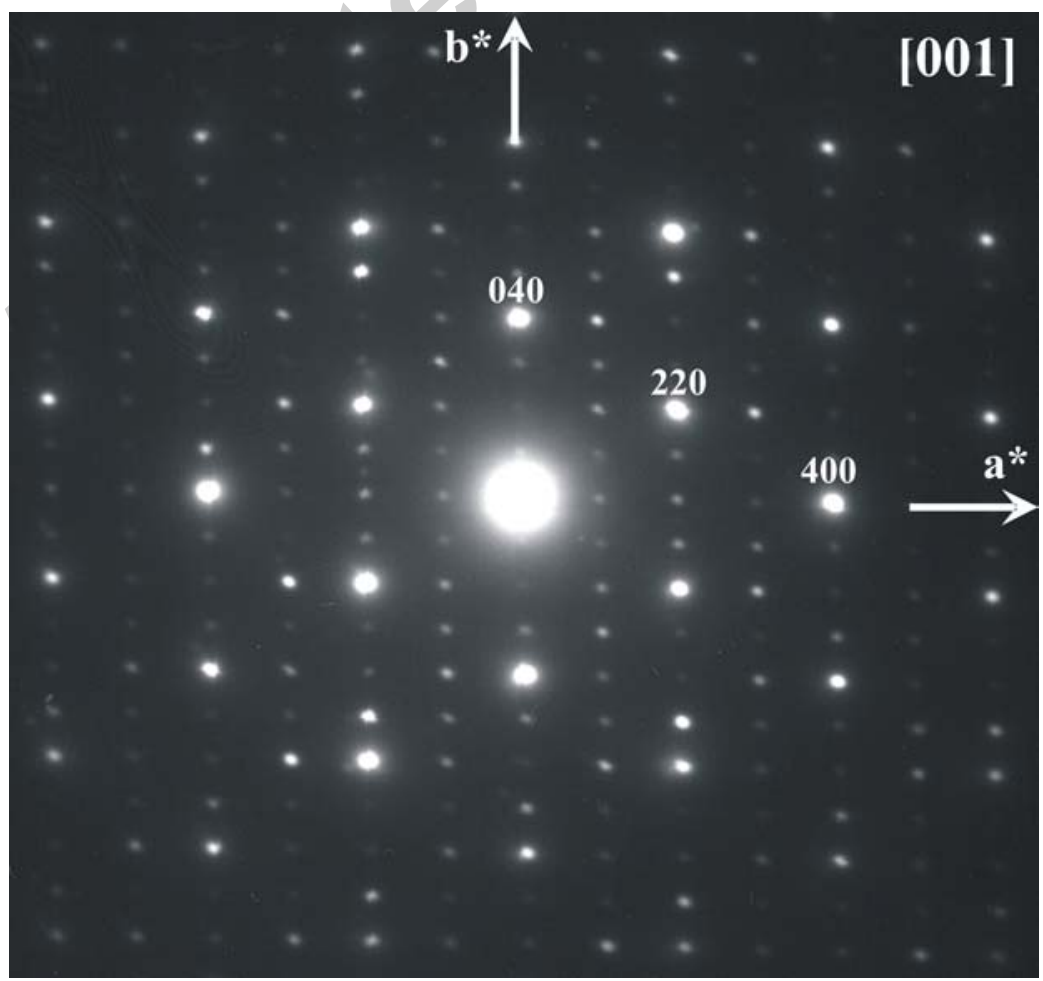




\section{Figure 4}

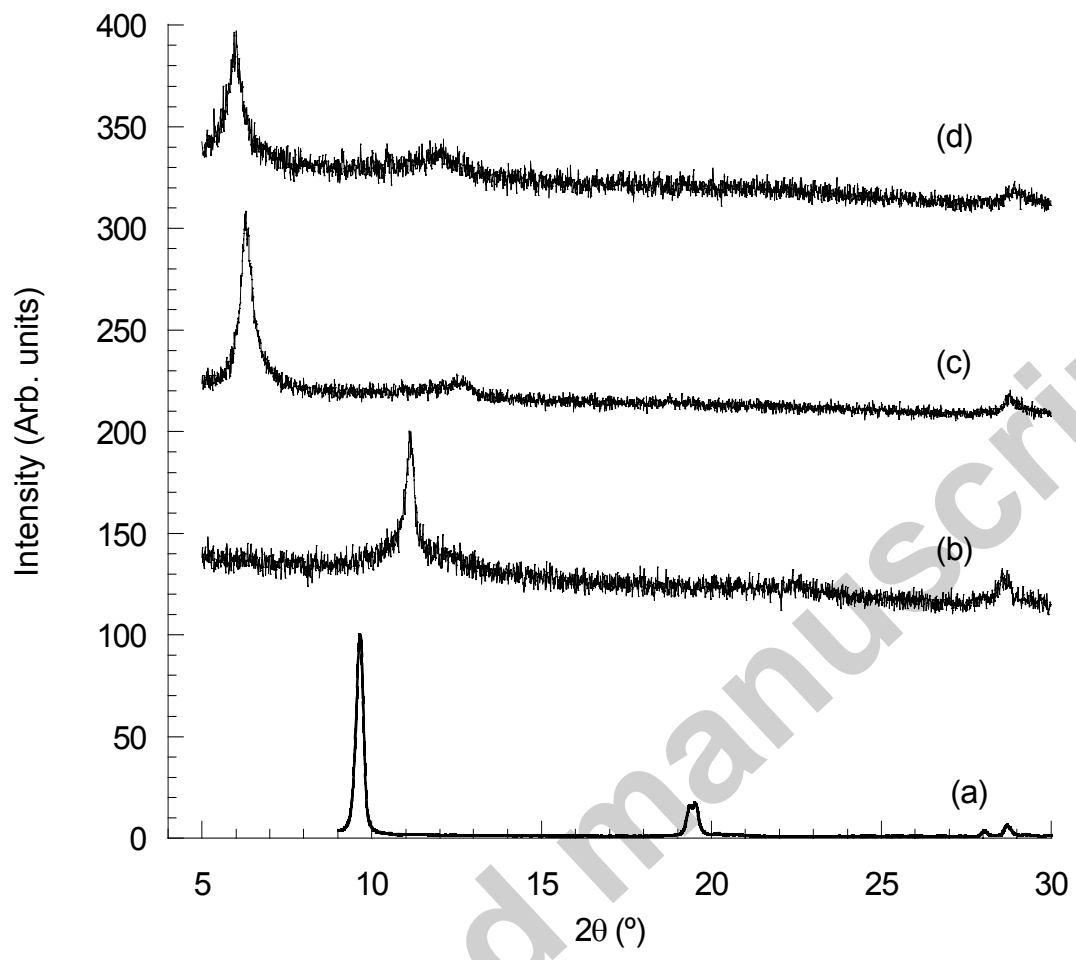


Figure 5

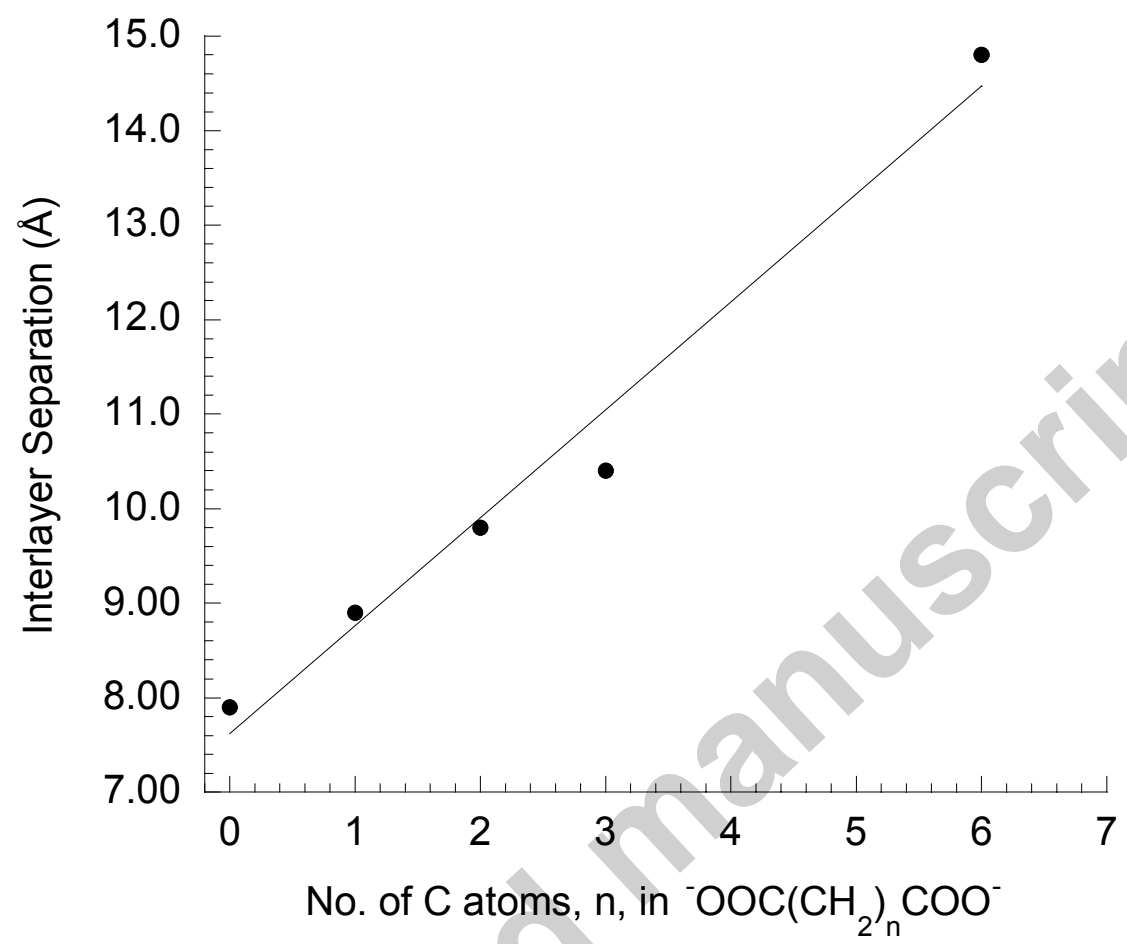




\section{Tables}

Table 1. Characterising data for the new layered hydroxide, $\mathrm{Y}_{2}(\mathrm{OH})_{5} \mathrm{NO}_{3} \cdot x \mathrm{H}_{2} \mathrm{O}$ and the anion exchange derivatives $\mathrm{Y}_{2}(\mathrm{OH})_{5} \mathrm{~A}_{0.5} \cdot x \mathrm{H}_{2} \mathrm{O}$.

\begin{tabular}{|c|c|c|c|c|}
\hline \multirow[b]{2}{*}{ A } & \multirow[b]{2}{*}{ Composition } & \multirow{2}{*}{$\begin{array}{c}\text { Interlayer } \\
\text { Separation } \\
(\AA)\end{array}$} & \multicolumn{2}{|c|}{ Elemental Analysis } \\
\hline & & & Observed (\%) & Calculated (\%) \\
\hline Nitrate & $\mathrm{Y}_{2}(\mathrm{OH})_{5} \mathrm{NO}_{3} \cdot \mathrm{H}_{2} \mathrm{O}$ & 9.18 & Y (49.89), N (3.91), H (2.25) & $\mathrm{Y}(50.53), \mathrm{N}(4.09), \mathrm{H}(2.06)$ \\
\hline Maleate & $\mathrm{Y}_{2}(\mathrm{OH})_{5}\left(\text { cis- } \mathrm{C}_{4} \mathrm{H}_{2} \mathrm{O}_{4}\right)_{0.5} \cdot 1.5 \mathrm{H}_{2} \mathrm{O}$ & 10.2 & $\mathrm{Y}(51.00) \mathrm{C}(6.84) \mathrm{H}(2.57)$ & $Y(51.25) \mathrm{C}(6.92) \mathrm{H}(2.62)$ \\
\hline Fumarate & $\mathrm{Y}_{2}(\mathrm{OH})_{5}\left(\text { trans }-\mathrm{C}_{4} \mathrm{H}_{2} \mathrm{O}_{4}\right)_{0.5} \cdot 1.5 \mathrm{H}_{2} \mathrm{O}$ & 9.6 & $\mathrm{Y}(50.88) \mathrm{C}(6.69) \mathrm{H}(2.59)$ & $\mathrm{Y}(51.26) \mathrm{C}(6.92) \mathrm{H}(2.62)$ \\
\hline Phthalate & $\mathrm{Y}_{2}(\mathrm{OH})_{5}\left(\mathrm{o}-\mathrm{C}_{8} \mathrm{H}_{4} \mathrm{O}_{4}\right)_{0.5} \cdot 1.5 \mathrm{H}_{2} \mathrm{O}$ & 14.0 & Y (47.31) C (12.94) H (2.92) & Y (47.68)C (12.88) H (2.97) \\
\hline Terephthalate & $\mathrm{Y}_{2}(\mathrm{OH})_{5}\left(\mathrm{p}-\mathrm{C}_{8} \mathrm{H}_{4} \mathrm{O}_{4}\right)_{0.5} \cdot 1.5 \mathrm{H}_{2} \mathrm{O}$ & 12.8 & $\mathrm{Y}(47.29) \mathrm{C}(12.78) \mathrm{H}(2.93)$ & $\mathrm{Y}(47.68) \mathrm{C}(12.88) \mathrm{H}(2.97)$ \\
\hline Oxalate & $\mathrm{Y}_{2}(\mathrm{OH})_{5}\left(\mathrm{C}_{2} \mathrm{O}_{4}\right)_{0.5} \cdot \mathrm{H}_{2} \mathrm{O}$ & 7.9 & Y (50.66) C (3.93) H (2.14) & $\mathrm{Y}(53.26) \mathrm{C}(3.690) \mathrm{H}(2.17)$ \\
\hline Succinate & $\mathrm{Y}_{2}(\mathrm{OH})_{5}\left(\mathrm{C}_{4} \mathrm{H}_{4} \mathrm{O}_{4}\right)_{0.5} \cdot 1.5 \mathrm{H}_{2} \mathrm{O}$ & 9.8 & $\mathrm{C}(6.91) \mathrm{H}(2.89)$ & $\mathrm{C}(6.90) \mathrm{H}(2.88)$ \\
\hline Glutarate & $\mathrm{Y}_{2}(\mathrm{OH})_{5}\left(\mathrm{C}_{5} \mathrm{H}_{6} \mathrm{O}_{4}\right)_{0.5} \cdot 1.5 \mathrm{H}_{2} \mathrm{O}$ & 10.4 & $\mathrm{C}(8.05) \mathrm{H}(2.88)$ & $\mathrm{C}(8.46) \mathrm{H}(3.12)$ \\
\hline Suberate & $\mathrm{Y}_{2}(\mathrm{OH})_{5}\left(\mathrm{C}_{8} \mathrm{H}_{12} \mathrm{O}_{4}\right)_{0.5} \cdot \mathrm{H}_{2} \mathrm{O}$ & 14.8 & $\mathrm{C}(13.96) \mathrm{H}(3.48)$ & $\mathrm{C}(13.09) \mathrm{H}(3.57)$ \\
\hline Decylsulfonate & $\mathrm{Y}_{2}(\mathrm{OH})_{5}\left(\mathrm{C}_{10} \mathrm{H}_{21} \mathrm{SO}_{4}\right) \cdot \mathrm{H}_{2} \mathrm{O}$ & 23.8 & $\mathrm{C}(21.70) \mathrm{H}(5.39)$ & $\mathrm{C}(22.78) \mathrm{H}(5.54)$ \\
\hline
\end{tabular}


Electronic Supplementary Information for 'Synthesis and anion exchange chemistry of new intercalation hosts containing lanthanide cations, $\mathrm{Ln}_{2}(\mathrm{OH})_{5}\left(\mathrm{NO}_{3}\right) \cdot x \mathrm{H}_{2} \mathrm{O}(\mathrm{Ln}=\mathrm{Y}, \mathrm{Gd}-\mathrm{Lu})^{\prime}$ Laura J. McIntyre, Lauren K. Jackson and Andrew M. Fogg

$\mathrm{Y}_{2}(\mathrm{OH})_{5} \mathrm{NO}_{3} . x \mathrm{H}_{2} \mathrm{O}$

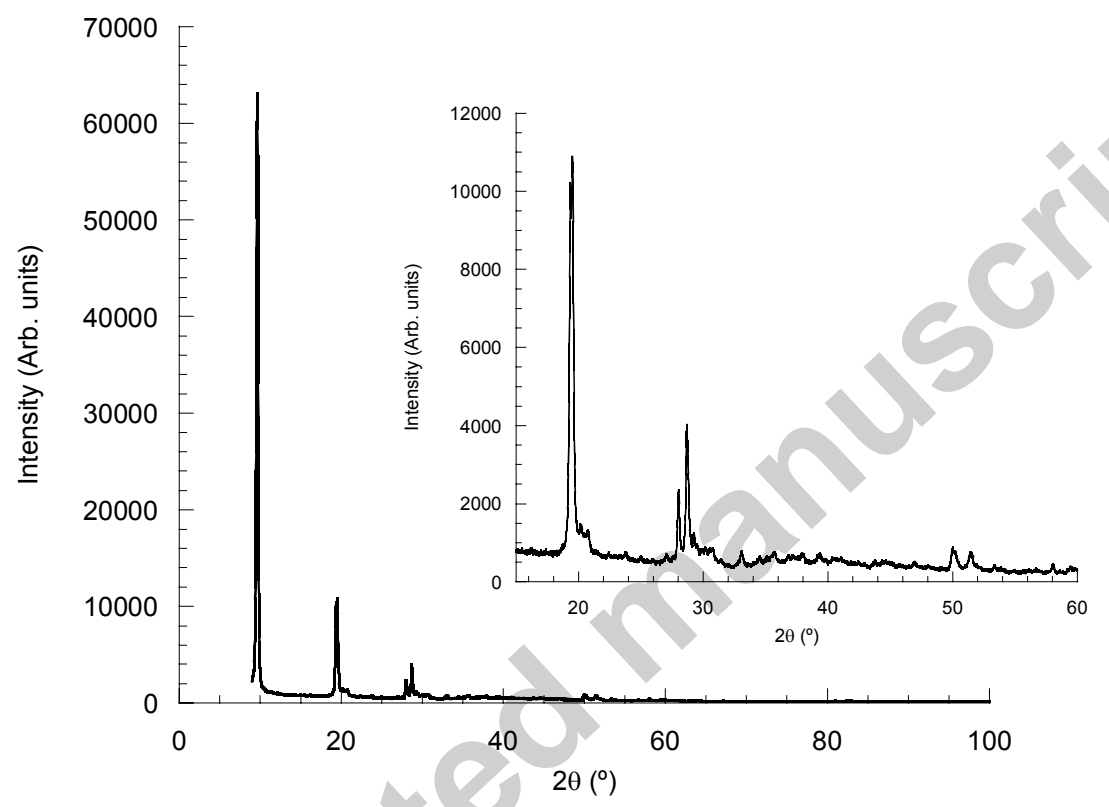

Fig. S1 Powder X-ray diffraction pattern of $\mathrm{Y}_{2}(\mathrm{OH})_{5} \mathrm{NO}_{3} \cdot x \mathrm{H}_{2} \mathrm{O}$. 


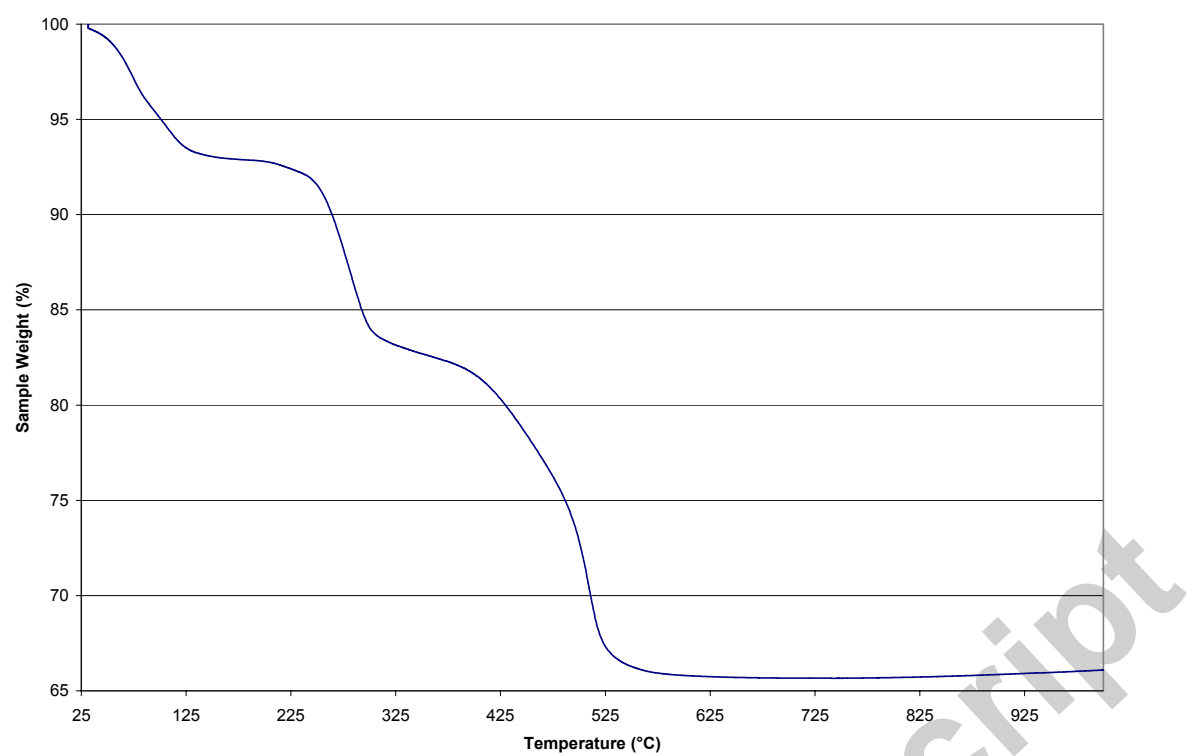

Fig. S2 TGA trace for $\mathrm{Y}_{2}(\mathrm{OH})_{5} \mathrm{NO}_{3} \cdot x \mathrm{H}_{2} \mathrm{O}$ showing mass losses of $6.86 \%$ below $150{ }^{\circ} \mathrm{C}$ and further mass losses of $9.79 \%$ by $350{ }^{\circ} \mathrm{C}$ and $17.28 \%$ by $600{ }^{\circ} \mathrm{C}$. 


\section{Anion Exchange Derivatives of $\mathrm{Y}_{2}(\mathrm{OH})_{5} \mathrm{NO}_{3} \cdot x \mathrm{H}_{2} \mathrm{O}$}

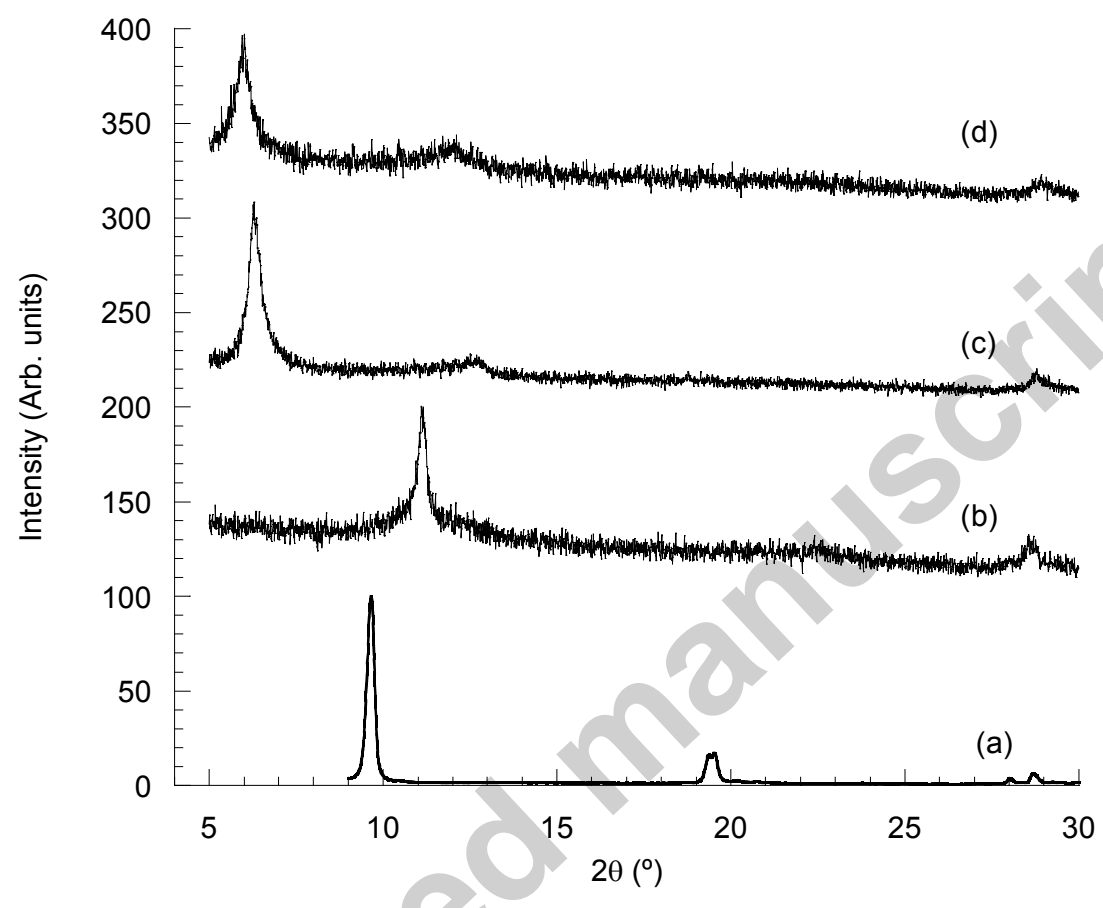

Fig. S3 Powder X-ray diffraction patterns of (a) $\mathrm{Y}_{2}(\mathrm{OH})_{5} \mathrm{NO}_{3} \cdot x \mathrm{H}_{2} \mathrm{O}$ and the anion exchange derivatives with (b) oxalate, (c) phthalate and (d) suberate. 


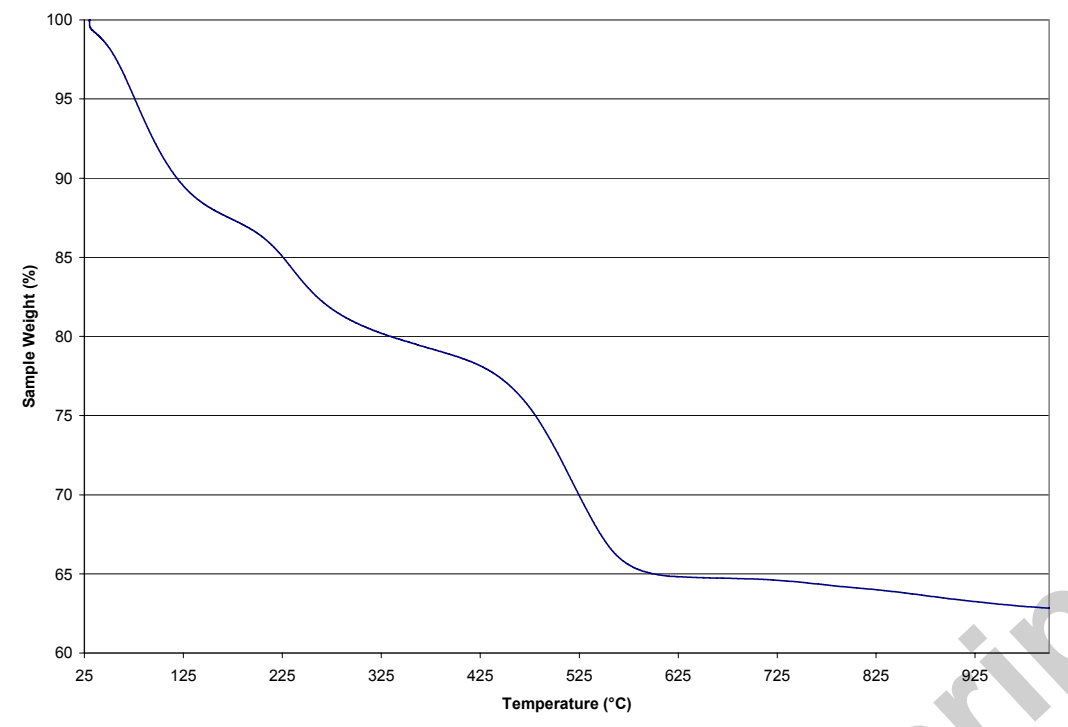

Fig. S4 TGA trace for $\mathrm{Y}_{2}(\mathrm{OH})_{5}\left(\mathrm{o}-\mathrm{C}_{8} \mathrm{H}_{4} \mathrm{O}_{4}\right)_{0.5} \cdot x \mathrm{H}_{2} \mathrm{O}$ showing a total mass loss of $37.14 \%$ by $1000{ }^{\circ} \mathrm{C}$.

Table S1 Characterising data for the organic anion exchange derivatives of $\mathrm{Y}_{2}(\mathrm{OH})_{5} \mathrm{NO}_{3} \cdot x \mathrm{H}_{2} \mathrm{O}$.

\begin{tabular}{|c|c|c|c|c|}
\hline \multirow[b]{3}{*}{ A } & \multirow[b]{3}{*}{ Composition } & \multirow{3}{*}{$\begin{array}{l}\text { Interlayer } \\
\text { Separation } \\
(\AA)\end{array}$} & \multicolumn{2}{|c|}{ Elemental Analysis } \\
\hline & & & Observed & Calculated \\
\hline & & & $(\%)$ & $(\%)$ \\
\hline \multirow[t]{3}{*}{ Maleate } & $\mathrm{Y}_{2}(\mathrm{OH})_{5}\left(\text { cis- } \mathrm{C}_{4} \mathrm{H}_{2} \mathrm{O}_{4}\right)_{0.5} \cdot 1.5 \mathrm{H}_{2} \mathrm{O}$ & 10.2 & $\mathrm{Y}(51.00)$ & $\mathrm{Y}(51.25)$ \\
\hline & & & $\mathrm{C}(6.84)$ & $\mathrm{C}(6.92)$ \\
\hline & & & $\mathrm{H}(2.57)$ & $\mathrm{H}(2.62)$ \\
\hline \multirow[t]{3}{*}{ Fumarate } & $\mathrm{Y}_{2}(\mathrm{OH})_{5}\left(\text { trans- } \mathrm{C}_{4} \mathrm{H}_{2} \mathrm{O}_{4}\right)_{0.5} \cdot 1.5 \mathrm{H}_{2} \mathrm{O}$ & 9.6 & $\mathrm{Y}(50.88)$ & $Y(51.26)$ \\
\hline & & & $\mathrm{C}(6.69)$ & $\mathrm{C}(6.92)$ \\
\hline & & & H (2.59) & $\mathrm{H}(2.62)$ \\
\hline \multirow[t]{2}{*}{ Phthalate } & $\mathrm{Y}_{2}(\mathrm{OH})_{5}\left(\mathrm{o}-\mathrm{C}_{8} \mathrm{H}_{4} \mathrm{O}_{4}\right)_{0.5} \cdot 1.5 \mathrm{H}_{2} \mathrm{O}$ & 14.0 & $\mathrm{Y}(47.31)$ & Y (47.68) \\
\hline & & & $\mathrm{C}(12.94)$ & $\mathrm{C}(12.88)$ \\
\hline
\end{tabular}




\begin{tabular}{|c|c|c|c|c|}
\hline & & & $\mathrm{H}(2.92)$ & $\mathrm{H}(2.97)$ \\
\hline \multirow[t]{3}{*}{ Terephthalate } & $\mathrm{Y}_{2}(\mathrm{OH})_{5}\left(\mathrm{p}-\mathrm{C}_{8} \mathrm{H}_{4} \mathrm{O}_{4}\right)_{0.5} \cdot 1.5 \mathrm{H}_{2} \mathrm{O}$ & 12.8 & $\mathrm{Y}(47.29)$ & $\mathrm{Y}(47.68)$ \\
\hline & & & $\mathrm{C}(12.78)$ & $\mathrm{C}(12.88)$ \\
\hline & & & $\mathrm{H}(2.93)$ & H (2.97) \\
\hline \multirow[t]{3}{*}{ Oxalate } & $\mathrm{Y}_{2}(\mathrm{OH})_{5}\left(\mathrm{C}_{2} \mathrm{O}_{4}\right)_{0.5} \cdot \mathrm{H}_{2} \mathrm{O}$ & 7.9 & Y (50.66) & $\mathrm{Y}(53.26)$ \\
\hline & & & C (3.93) & C (3.690) \\
\hline & & & $\mathrm{H}(2.14)$ & $\mathrm{H}(2.17)$ \\
\hline \multirow[t]{2}{*}{ Succinate } & $\mathrm{Y}_{2}(\mathrm{OH})_{5}\left(\mathrm{C}_{4} \mathrm{H}_{4} \mathrm{O}_{4}\right)_{0.5} \cdot 1.5 \mathrm{H}_{2} \mathrm{O}$ & 9.8 & $\mathrm{C}(6.91)$ & $\mathrm{C}(6.90)$ \\
\hline & & & $\mathrm{H}(2.89)$ & $\mathrm{H}(2.88)$ \\
\hline \multirow[t]{2}{*}{ Glutarate } & $\mathrm{Y}_{2}(\mathrm{OH})_{5}\left(\mathrm{C}_{5} \mathrm{H}_{6} \mathrm{O}_{4}\right)_{0.5} \cdot 1.5 \mathrm{H}_{2} \mathrm{O}$ & 10.4 & $\mathrm{C}(8.05)$ & $\mathrm{C}(8.46)$ \\
\hline & & & $\mathrm{H}(2.88)$ & $\mathrm{H}(3.12)$ \\
\hline \multirow[t]{2}{*}{ Suberate } & $\mathrm{Y}_{2}(\mathrm{OH})_{5}\left(\mathrm{C}_{8} \mathrm{H}_{12} \mathrm{O}_{4}\right)_{0.5} \cdot \mathrm{H}_{2} \mathrm{O}$ & & $\mathrm{C}(13.96)$ & C (13.09) \\
\hline & & & $\mathrm{H}(3.48)$ & $\mathrm{H}(3.57)$ \\
\hline \multirow[t]{2}{*}{ Decylsulfonate } & $\mathrm{Y}_{2}(\mathrm{OH})_{5}\left(\mathrm{C}_{10} \mathrm{H}_{21} \mathrm{SO}_{4}\right) \cdot \mathrm{H}_{2} \mathrm{O}$ & 23.8 & $\mathrm{C}(21.70)$ & $\mathrm{C}(22.78)$ \\
\hline & & & $\mathrm{H}(5.39)$ & H (5.54) \\
\hline
\end{tabular}

